\title{
THE INFLUENCE OF ENNIUS ON SILIUS ITALICUS
}

\section{K.O. Matier, University of Durban-Westville}

In the twelth book of the Punica, Silius records the fact that one of the combatants in the Sardinian campaign was none other than the poet Ennius. After he made himself conspicuous by killing many of the enemy, he was attacked by Hostius. He was saved by Apollo, who paid him the following tribute:

sacer hic ac magna sororum

Aonidum cura est et dignus Apolline vates.

hic canet illustri primus bella Itala versu attolletque duces caelo; resonare docebit hic Latiis Helicona modis nec cedet honore Ascraeo famave seni.

"That sacred head is dearly loved by the Muses, and he is a bard worthy of Apollo. He shall be the first to sing of Roman wars in noble verse, and shall exalt their commanders to the sky; he shall teach Helicon to repeat the sound of Roman poetry, and he shall equal the sage of Ascra in glory and honour."

(translated Duff)

Scholars have long debated whether Silius was indebted to Ennius or not and if so, to what extent. The view of Heynacher (1877:68) that Silius used Ennius as his principal source for historical events has been shown by Bauer (1884:105-106), Klotz (1933:1-2) and Nicol (1936:125) to be fundamentally wrong. Only Books 8 and 9 of Ennius' Annales deal with the events of the Second Punic War while Silius devotes 17 whole books to the topic. This fact alone would have made any extensive adaptation of Ennian passages by Silius physically impossible.

Wezel has written a dissertation in Latin on the sources of the Punica which I find utterly unconvincing (1873: footnote 1). After citing some 27 pages of phrases and whole lines which he believes Silius has borrowed from Ennius, he is forced to make three most damning admissions (1873:46-47):

1. Very many Ennian passages could not be taken over by Silius without adaptation as the diction was too unpolished for contemporary taste.

The attitude of Silius' contemporaries to Ennius will be discussed later in this paper but it is significant that Wezel feels uneasy that Ennius' diction was too rough and unpolished for them.

2. He cites Vahlen's estimate that out of 18 books of the Annales, scarcely the equivalent of a third of one book has survived.

3. He concedes that most of the fragments of Ennius have come down to us in the works of grammarians and scholiasts who quote the passages simply because there is some anomaly in them.

In spite of her valid criticism of Wezel for what she calls "an over-zealous selection of fancied resemblances, many of which are, in truth, more imaginary than real" (1910:357) 
and in spite of her warning that "to attempt to reach any final conclusion as to the exact amount of influence exercised by the early annalists and especially by Ennius, would likewise be useless, when so little of their work is left to us" (1910:359), Miss Woodruff falls into the same trap as Wezel and cites many passages where the differences between Ennius and Silius are more striking than the resemblances. In other passages, such as the funeral of Paulus (10.529ff.) where ash-trees, tall poplars, holm-oaks, pine-trees and cypresses are felled, she fails to convince that Silius is wholly indebted to Ennius (1910:365-367). Von Albrecht has shown (1964:163) that all the words cited are also found in Virgil (Aen. 6.180ff.) and Lucan (3.440ff.). She is so much under the influence of Vahlen (1903: intro. $x x i-c x x x)$ that at times she seems to suspend all critical judgement: "he has given such a complete review of the proof of Ennian influence upon contemporary and succeeding writers, as to leave little need to say more" (1910:359).

I have made a detailed study of a passage in Book 11 of Silius which Miss Woodruff alleges is taken from Ennius:

at patulo surgens iam dudum ex aequore late nauticus implebat resonantia litora clamor, et, simul adductis percussa ad pectora tonsis, centeno fractus spumabat verbere pontus.

$(487-490)$

"The shouts of the sailors, which had long been rising far and wide from the open sea, filled the resounding shores. As soon as the oars were brought up and struck the rowers on the chest, the sea foamed, broken by a hundred blows."

Ennius has:

poste recumbite vestraque pectora pellite tonsis; pone petunt: exim referunt ad pectora tonsas.

(Ann. 245-246(W))

"Lean right backward and beat your breasts with the oars;

Backward they reach, then pull again the oars to their breasts."

Miss Woodruff comments as follows: "in the first of these, with its similar metrical effect at the close and its similar form of the noun tonsa, there is the same thought that we meet in Silius, namely of striking the breast with the oars: in the second, while this emphatic idea of striking is moderated in the milder referunt, the general effect is much the same, and the phrasing of the three closing words ad pectora tonsas certainly leaves no doubt as to the origin of ad pectora tonsis in Silius" (1910:373). But it is equally possible that Silius may have had a line of Valerius in mind, as Fürstenau (1916:46) suggests:

tum valida Clymenus percusso pectore tonsa

frater et Iphiclus puppem trahit.

(Val. Fl. 1.369-370)

"Next Clymenus, striking his breast with the strong oar, and his brother Iphiclus move the vessel."

It should, however, be borne in mind that it is impossible to prove conclusively that Silius used Valerius as a source for the Punica (Matier 1983:79-80). Silius may well have had 
Ennius in mind here but in general his debt to his predecessor is likely to have been more in form and method rather than in the details of subject matter.

Miss Woodruff (1910:409-410) is equally unconvincing in her treatment of omens. A good example of this is her assertion that Silius' description of the eruption of Vesuvius (8.653655) may owe something to Ennius. Forsyth (1990:4-9) has convincingly shown that Silius projects backward in time the eruption which he himself experienced in AD 79. (I am grateful to Professor Barry Baldwin for sending me a copy of this article.) The weakness of Woodruff's case is aptly illustrated by her conclusion on omens. "It is clear that their origin is to be referred to various sources and among these Ennius probably (my italics) exerted no small influence. We know that he related dreams and auguries and that he told of eclipses and it would be but reasonable to suppose (again my italics) that he also recorded some of the traditional portents with which Rome and Italy were filled during his lifetime" (1910:421).

In his Latin dissertation on Silius' alleged imitation of Ennius, Fürstenau, whom I have mentioned briefly in the discussion of the nautical passage in Ennius, takes the opposite view to that of Wezel and Woodruff. He is guilty of making sweeping statements such as:

1. Silius never read or imitated Ennius at all (1916:8).

2. None of Silius' contemporaries had read Ennius either (1916:8-16).

3. Silius' knowledge of Ennius came exclusively from Virgil and Cicero (1916:17ff.).

The first of these statements is so outrageous that it deserves no further comment and the third is impossible to prove one way or the other so I shall concentrate on the second. It is true that Ennius seems to have been despised in the Silver Age. Skutsch (1985:13-14) cites the following illuminating anecdote from Cassiodorus:

Vergilius dum Ennium legeret a quodam quid ageret inquisitus respondit "aurum in stercore quaero".

(Inst. 1.1.8)

"While reading Ennius, Virgil was asked by someone what he was doing, he replied 'I'm looking for gold in a dung-heap'."

Skutsch is rightly sceptical about Virgil being guilty of such scatological abuse. "What we know about the personality of Virgil makes it very unlikely that the story is true; his obvious indebtedness to the older poet will have caused it to be invented in the Neronian period when Virgil was admired and Ennius despised" (1985:14). Skutsch shows that while Propertius and Ovid were critical of Ennius, Ovid on the other hand does show some respect (1985:15). Persius and Statius are not entirely negative either (1985:16-17). Skutsch continues: "less favourable is the judgement of Martial, who expresses astonishment $(5.10 .7)$ that Ennius should have been read while Virgil was alive (forgetting that the Aeneid could be read only after Virgil's death), and is struck with amazement at Ennius' old-fashioned terrai frugiferai (11.90.5)" (1985:17). Skutsch singles out Seneca as the "extreme representative of the hostility towards the early poets which characterizes his time" (1985:29). None of this is proof of Fürstenau's second allegation. Hostility towards Ennius is one thing; complete ignorance of the early poet quite another. As Miss Woodruff remarks: "even this attitude (of hostility) shows that Ennius was still known and read. Seneca would surely not have hinted at his dislike of this poet, if he had been unacquainted with his writings" (1910:360-361). Ennius was certainly a great survivor, as Skutsch illustrates. "The contempt which many of the Neronian intellectuals felt for the early poets 
is bound to have discouraged the production of copies; but when the Antonine period reversed their judgement and admired Ennius, many copies, quite apart from those deposited in the great State Libraries, must still have been available" (1985:10). Aulus Gellius (18.5.2-7) mentions an Ennianista, a connoisseur of Ennius' poems, who recited the Annals to the people in the theatre. We know from Pliny (Epist. 3.7.8) that Silius had an extensive library and I have not the slightest doubt that with his antiquarian interests, he would have included Ennius in his collection.

The best modern treatment of the relationship between Silius and Ennius is that of von Albrecht (1964:161-164). He shows that while the influence of Ennius is considerable, it is to be found more in general aspects than in detail. Silius is closer to Ennius than to Virgil in his use of historical material and also in the chronological arrangement of this material. The plurality of heroes is common to both writers:

Ordior arma, quibus caelo se gloria tollit

Aeneadum

"Here I begin the war by which the fame of the Aeneadae was raised to heaven."

Silius says of Ennius, as we have seen:

hic canet illustri primus bella Itala versu attolletque duces caelo.

"He shall be the first to sing of wars in noble verse and shall exalt their commanders to the sky."

The combination superumque hominumque (1.152) and divumque hominumque (2.484) also seems to be Ennian (Ann. 225, $448 \mathrm{~W}$ ). Von Albrecht also cites examples of an Ennian formula used by Silius in what he calls a moral-philosophical situation:

(Virtus to Scipio):

nec ferro mentem vincere nec auro

"neither steel nor gold will ever master your mind."

(Ennius on Manius Curius Dentatus):

quem nemo ferro potuit superare nec auro (Ann. $209(\mathrm{~W}))$

"whom none could vanquish with the sword nor bribe with gold."

at, quis aetherii servatur seminis ortus, caeli porta patet. 
"On the other hand the gate of heaven stands open to those who

have preserved the divine element born within them."

(translated Duff)

(Africanus in Ennius):

Si fas endo plagas caelestum ascendere cuiquam est, mi soli caeli maxima porta patet.

(Epigrams 3-4 (W))

"If it is right for anyone to go up into the regions of heaven's dwellers, for me alone heaven's great gate lies open."

Von Albrecht concludes by remarking that artistically, Virgil has taken the place of Ennius most of all and Silius, by identifying himself so closely with Virgilian form, has contributed to the fact that the Annals have fallen into oblivion (1964:164).

Skutsch also has some very perceptive comments on Ennius and Silius. He believes that Silius may have intended to write an eighteenth book, "the last, the seventeenth, showing unmistakeable signs of being completed in haste to bring the story to an end, probably because of the painful illness which led to the poet's suicide. It is very doubtful, however, whether that number was chosen because the Annals had eighteen books" (1985:17). Tnis is the view of Wistrand (1956:60) where, however, it is significant that he uses the words "Perhaps Bickel is right in his supposition that Silius originally had the intention of giving his epic 18 books following the example of Ennius" (Martin 1946:163-165; Wallace 1958:99-103).

Klotz (1927:83) has argued that Silius' praise of Ennius' heroic exploits in Sardinia (12.393ff.) is proof of a mention in the Annals of the poet's military service. Skutsch is far from convinced. "Silius certainly does not give reliable help in establishing the context of Ennian fragments. Blass conclusively proved this in his review of Wezel" (1985:18). The same applies to an address by Hannibal to his troops. Livy tells us $(21.45 .6)$ that this took place before the battle at Ticinus in 218 BC. Silius (9.209-211) places it before Cannae. Skutsch points out that "the corresponding fragment of the Annals (VII.xx) cannot be placed with certainty; but even if Ennius had it in the same context as Silius, it does not follow that Silius depended on him" (1985:18).

Another modern attempt to use Silius for the reconstruction of certain ideas of Ennius is that of Bettini (1979: passim) but his arguments fail to convince.

The lasting contribution made by Ennius was more intangible than concrete. It is to be found more in the spirit and tone of the Punica rather than in specific details. As I have shown elsewhere (1989:5), Silius was a conservative old Roman gentleman who continually looked back to the glorious days of the old Roman republic. As a reaction against the age of rhetoric and epigram, he turned for inspiration to a glorious episode from Rome's past. Like Ennius, he wrote a poem of national glorification, what the Romans called a carmen togatum. As Vessey puts it (1982:64: "That Silius should revere Ennius at all is a portent, showing him to be a harbinger of second-century archaism... The precise contribution of Ennius' Annales to Silius' Punica is indeterminable but even lip service testifies to an attitude of mind". 


\section{BIBLIOGRAPHY}

Bauer, L. 1884. Das Verhaltnis der Punica des C. Silius ltalicus zur dritten Dekade des Livius. Acta Seminarii Philologi Erlangensis 3, 103-160, esp. 105-106.

Bettini, M. 1979. Studi e note su Ennio. Pisa., 143-171.

Bickel, E. 1911. De Silii Punicorum libris SS. post Domitianum abolitum editis. RhM 66, 500-512.

Blass, H. 1874. Jahrb. f. class. Philologie 120, $506 \mathrm{ff}$.

Forsyth, P.Y. 1990. "An Eruption of Vesuvius in 217 BC?", The Ancient History Bulletin, 4.1, 4-9.

Fürstenau, G. 1916. De Silii Italici imitatione quae fertur Enniona. Diss. Berlin.

Häussler, R. 1978. Das historische Epos von Lucan bis Silius und seine Theorie. Studien zum historischen Epos der Antike. Heidelberg, 148-161.

Heynacher, M. 1874. Über die Quellen des Silius Italicus. Diss. Jena.

Heynacher, M. 1877. Über die Stellung des Silius Italicus unter den Quellen zum zweiten punischen Kriege. Gymn. Progr. Ilfeld.

Klotz, A. 1927. Silius Italicus. RE 2, Reihe 5, 82-83.

Klotz, 1933. Die Stellung des Silius Italicus unter den Quellen zur Geschichte des zweiten punischen Krieges. RhM 82, 1-34.

Martin, J. 1946. "Die Punica des Silius", WJA 1, 163-165.

Matier, K.O. 1983. "The Poetic Sources of Silius Italicus with particular reference to Book Eleven", A. Class. XXVI, 79-80.

Matier, K.O. 1989. Silius Italicus at Bay: Pliny, Prejudice and the Punica. Inaugural Address, Univ. of Durban-Westville, 5 October, 5.

Nesselrath, H.G. 1986. "Zu den Quellen des Silius Italicus", Hermes 114, 203-230.

Nicol, J. 1936. The historical and geographical sources used by Silius Italicus. Oxford, 124-125.

Skutsch, O. 1985. The Annals of Quintus Ennius. Oxford.

Vahlen, J. 1903. Ennianae Poesis Reliquiae. Leipzig.

Vessey, D.W.T.C. 1982. Cambridge History of Classical Literature, Vol. II. Latin Literature. Cambridge.

Von Albrecht, M. 1964. Silius Italicus. Freiheit und Gebundenheit romischer Epik. Amsterdam.

Wallace, M.V.T. 1958. "The Architecture of the Punica, a Hypothesis", CPh 53, 99-103.

Wezel, E. 1873. De C. Silii Italici cum fontibus tum exemplis. Diss. Leipzig.

Wistrand, E. 1956. "Die Chronologie der Punica des Silius Italicus", Arsskrift 62, 60.

Woodruff, L.B. 1910. "Reminiscences of Ennius in Silius Italicus", Univ. of Michigan Studies 4, 355-424. 